\title{
Indicators of Tax Authority Monitoring: Firm Characteristics, Tax Avoidance and Reinvestment Allowance Utilisation
}

\author{
Fairus Halizam A. Hamzah ${ }^{a}$ \\ Nadiah Abd Hamid ${ }^{b}$ \\ Siti Noor Hayati Mohamed Zawawi ${ }^{c}$ \\ Rohayu Yusup ${ }^{d}$ \\ Norazah Md Azali ${ }^{\mathrm{a}}$ \\ Universiti Teknologi MARA
}

\begin{abstract}
The Inland Revenue Board of Malaysia (IRBM) provides a monitoring mechanism of corporate governance through tax audits. However, indicators associated with the tax authority monitoring system remain underexplored due to data confidentiality. This study aims to examine the indicators used by the tax authority in performing tax monitoring where the tax return data of firms that claim reinvestment allowance (RA) were employed alongside the historical audit data of corporate taxpayers of both a tax-monitored firm and an unmonitored tax firm. The results of the analysis reported that the tax authority monitoring system is closely associated with fundamental details disclosed in the tax return namely, assessment year, profitability, scale of operation, firm directorship, tax consultancy and industry type. In contrast, the incidents of tax avoidance and incentive utilisation indicators were not prominent in tax authority monitoring. The investigation of firms that experienced tax monitoring provides insight into indicators which interest tax authorities when it comes to a firm's tax audit. This research revealed new evidence on IBRM preferred indicators in conducting tax monitoring.
\end{abstract}

Keywords: Corporate governance, firm characteristics, tax auditing, tax incentive, taxation JEL classification: G3, M42, E62, H32, E62

a Faculty of Accountancy, Universiti Teknologi MARA, 42300 Shah Alam, Selangor, Malaysia. Email: 2017830058@ isiswa.uitm.edu.my, Fairuzhalizam@gmail.com (Corresponding author)

b Faculty of Accountancy, Universiti Teknologi MARA, 42300 Shah Alam, Selangor, Malaysia. Email: nadiah201@ uitm.edu.my

c Faculty of Accountancy, Universiti Teknologi MARA, 42300 Shah Alam, Selangor, Malaysia. Email: siti_n@ uitm.edu.my

d Faculty of Accountancy, Universiti Teknologi MARA, 42300 Shah Alam, Selangor, Malaysia. Email: rohayu831@ uitm.edu.my

e Faculty of Accountancy, Universiti Teknologi MARA, 42300 Shah Alam, Selangor, Malaysia. Email: noraz028@ uitm.edu.my

* Acknowledgement: We would like to acknowledge the endless support from the Institute of Graduate Studies (IPSIS) and the Faculty of Accountancy, UiTM. We are also indebted to the Inland Revenue Board of Malaysia for authorising the use of privileged data to one of the authors in this research. The confidential tax information received from IRBM is highly guarded in this research. Statistical aggregates were used so that taxpayers cannot be identified. All opinions are those of the authors and do not reflect the views of IRBM. Lastly, we are grateful to audiences at the 2nd FGIC Conference on Governance and Integrity 2019 (FGIC2019) for their thoughts and suggestions. The research is funded by the Universiti Teknologi MARA through the LESTARI grant ref. no.: 600-IRMI/DANA/KCM/5/3/LESTARI (143/2017).

Article Info: Received 6 January 2020; Revised 1 October 2020; Accepted 25 October 2020

https://doi.org/10.22452/MJES.vol57no2.8 


\section{Introduction}

A tax audit conducted by relevant tax authorities is valuable in corporate governance function. The function of corporate governance as demonstrated in tax audit involves reporting unrecognised tax benefits (Brushwood, Johnston, \& Lusch, 2018), detecting tax avoidance (Bozanic, Thornock, Hoopes, \& Williams, 2017; Kubick, Lockhart, Mills, \& Robinson, 2017; Hoopes, Mescall, \& Pittman, 2012), promoting good financial reporting (Hanlon, Hoopes, \& Shroff, 2014), identifying income-shift decisions in multinational corporations (Beuselinck, Deloof, \& Vanstraelen, 2014), reducing the cost of debt financing (Guedhami \& Pittman, 2008), deterring conflicts of interest among stakeholders as well as increasing the market value of the firm's share (Desai, Dyck, \& Zingles, 2007). These corporate governance functions were well-investigated and documented by previous researchers. The outcomes from these previous researches confirm the role of tax audit in strengthening corporate governance, attracting considerable attention from taxpayers, governments, policymakers and tax researchers.

Despite this scenario, little has been reported on how relevant tax authorities carry out the role and responsibilities of corporate governance. For instance, the selection of the tax audit process has not been fully explored especially in identifying the different indicators used by tax authorities when conducting tax monitoring. Due to strict data confidentiality, only a few researchers managed to highlight this question previously. The use of public disclosure in financial statements and the tax avoidance measurement employed for audit selection was studied by Bozanic et al. (2017) while Hanlon et al. (2014) used a firm's assets, coordinated industry, and proximity of tax headquarters to indicate tax audit probability where they managed to extract data from the IRS's (Internal Revenue Services) Audit Management Information Reporting System (AIMS).

Similarly, Kubick et al. (2017) found that the distance of tax offices may serve as an indicator in the likelihood of an IRS audit. While previous studies focused upon tax authority activities related to tax avoidance elements and firm characteristics as possible indicators for audit selection, this study specifically examined incentivised firms that utilise reinvestment allowance (RA) since this incentive is one of Malaysia's most prominent corporate tax incentives (Bank Negara Malaysia, 2017). As compared to other investment tax incentives, ${ }^{1}$ RA is considered unique as it was exclusively derived from the Income Tax Act 1967, thus, is not under the jurisdiction of any other law or authority apart from the RA administration governed by IRBM. Based on Abd Hamid, Hamzah, Noor and Azali's (2018) study, RA was designed to encourage firms in the manufacturing sector to embrace modern automation projects. Hence, a tax audit becomes increasingly complex to ensure these incentivised firms achieve the intended objective of RA. In response to Henry and Sansing (2018), who mentioned the exclusion of loss firms in most research on tax, this study accounts for loss firms by including it as part of a sample as there is no restriction in claiming RA for this type of firms. The inclusion of RA utilisation and loss firms in this research provides variation in firm characteristics, thus allowing the examination of a full audit task.

1 Investment incentives such as pioneer status and investment tax allowance is approved by the Minister of Finance and Minister of International Trade and Industry and legislated under the Promotion of Investment Act 2007. 
This study was based on the confidential tax return data and historical tax audit records of taxpayers' profiles based on the case management system (CMS). Overall, these data offer insights into one IRBM monitoring mechanism aspect on incentivised firms, namely the set of firm disclosure that can be used in the creation of an audit case. Evidence shows that IRBM accesses available firm disclosures in the tax return and the result of an internal review, in order to build the audit case. Furthermore, the association between firm characteristics and the indicators of tax monitoring will be relevant to researchers, practitioners and taxpayers who use firm disclosure by the tax authority for both support and audit selection. Additionally, the irrelevant results of tax avoidance and tax incentive utilisation indicators are crucial for IRBM in strengthening their audit coverage. This study will be organised as follows: Section 2 presents the literature review and the hypothesis development while Section 3 outlines the sample selection and research design. Subsequently, Section 4 covers the empirical results, followed by the discussion in Section 5 , and the conclusion in Section 6 .

\section{Literature Review and Hypothesis Development}

\subsection{Tax Authority Monitoring}

The primary responsibilities of a tax authority are to regulate tax compliance (Murphy, 2008), collect income tax from individuals and business entities (Nessa, Schwab, Stomberg, \& Towery, 2016) besides administering tax administrative obligations (IRBM, 2018). In Malaysia, IRBM conducts two types of tax audits, namely the field and the desk audits. A field audit involves visiting a taxpayer's premise for a detailed examination of relevant documents where a review of documentation is attained from a taxpayer and an interview conducted at one of IRBM's offices. According to IRBM, a tax audit involves the examination of a taxpayer's business record as well as all its relevant financial affairs. The Malaysian Institute of Certified Public Accountants (MICPA), Malaysian Institute of Accountants (MIA) and Chartered Tax Institute of Malaysia (CTIM) (2019) confirmed that the tax audit carried out by IRBM is to ensure the income and tax liability declared by taxpayers are accurate and compliant with the Income Tax Act 1967.

Desai et al. (2007) established two critical insights on the importance and impact of tax audit on corporate governance. Firstly, a stricter tax audit strengthens corporate governance while tax revenue relies on the quality of corporate governance. These insights are consistent with studies by Guedhami and Pittman (2008) and Hoopes et al. (2012) who added that the impact of tax audit is stronger when other means of corporate governance are weak. Hanlon et al. (2014) further support Desai et al. (2007) research outcome by stating that tax authorities provide a monitoring mechanism that is associated with the quality of financial reporting. A recent research conducted by Tennant and Tracey (2019) reported that tax audit employed among large taxpayers has led to an increase in firm profitability and effective tax rate (ETR).

Previous literature predominantly highlights the importance of tax audit (Desai et al., 2007), the effects of tax audit (Brushwood et al., 2018; Hanlon et al., 2014), the likelihood and determinants of tax audit (Bozanic et al., 2017), the interaction between taxpayers and tax authority (Ayers, Seidman, \& Towery, 2017; Beuselinck et al., 2014) 
and how tax authority conducts an audit within given resources (Kubick et al., 2017; Nessa et al., 2016). This study examines the indicators of tax authority monitoring, concentrating on firms that claim RA based on the tax returns report where details such as firm characteristics and tax avoidance indicators are considered.

This study aims to answer the question of "What are the determinants or indicators employed by IRBM in fulfilling the governance role when executing tax authority monitoring?" The indicators used for selecting audit cases remains a mystery where only tax authorities hold the information about the selection process. However, the audit selection can be predicted as stated by Nessa et al. (2016) where they claimed that an understanding of tax authority's resources, such as the reduction or increase in the financial budgets and the strength of a tax authority's employees, would allow taxpayers to pre-empt the likelihood of facing a tax audit. A study by Hoopes et al. (2012) highlighted that firms can identify the trend of tax audit activities by paying attention to leadership and structural changes of the tax authority, government revenue trends, changes in financial accounting standards, hiring of former tax officers, having conversations with firms experiencing audits as well as analysing the historical annual audit coverage data released by the tax authority.

\subsection{Selection of Audit Cases}

Based on the Tax Audit Framework issued by IRBM, MICPA et al. (2019) revealed that selection of audit cases is carried out via a computerised system built on risk analysis criteria and various determinants such as business performance, financial ratios, type of industry, prior compliance records and third-party information. The selection of audit cases is also not limited to the outcome of the computerised system, as these cases may also be chosen based on the information obtained from different sources (IRBM, 2015). Examples of information obtained from these different sources include information received from a third party, specific industries, specific issues for a particular group of taxpayers and location. Information in the annual report released by the IRBM was reviewed where valuable information concerning tax audit executed by IRBM among corporate taxpayers were gathered. Some of the essential insights on tax audit are summarised in Table 1.

Although information in Table 1 may not be the latest data, tax audit executed by IRBM is confirmed to rely on various indicators and carried out based on a strategic approach. Moreover, the increasing number of resolved tax audit cases indicates the seriousness of IRBM in performing this governance role. This research explores the fundamental indicators or determinants of a tax audit, which leads to the understanding of tax audit coverage and area of interest.

\subsubsection{Firm Characteristics and Tax Authority Monitoring}

The analyses in this study are based on various indicators which tax authorities may consider before the decision for audit is being made. The most common indicators used by tax authorities in executing tax audit is argued to be based on firm characteristics where the tax authority gathers information on firm characteristics through the 
Table 1. Valuable information on tax authority monitoring activity

\begin{tabular}{|c|c|c|c|}
\hline Year & $\begin{array}{c}\text { Number of } \\
\text { audit cases } \\
\text { resolved }\end{array}$ & $\begin{array}{c}\text { Achievement } \\
\text { from targeted } \\
\mathrm{KPI}^{*}(\%)\end{array}$ & Strategies/preferences \\
\hline 2017 & 178,583 & 137.48 & $\begin{array}{l}\square \text { Implementation of Focus Audit executed in the field } \\
\text { audit. } \\
\square \text { Tax audit criteria based on risk analysis. } \\
\square \text { Digital economy. } \\
\square \text { Data mining and collaboration with other agencies. }\end{array}$ \\
\hline 2016 & 161,760 & 142.51 & $\begin{array}{l}\square \text { Implementation of audit on small and medium } \\
\text { enterprise (SMEs). } \\
\square \text { Segmented according to Industry Based Audit: } \\
\text { information and technology, services, manufac- } \\
\text { turing, professional, technical and scientific } \\
\text { activities and vehicle repair workshops. }\end{array}$ \\
\hline 2015 & 138,203 & 152.49 & $\begin{array}{l}\square \text { Introduction of Monitoring Deliberate Tax } \\
\text { Defaulters (MDTD) program focusing on non- } \\
\text { compliance taxpayers. } \\
\square \text { Transfer pricing and high-income taxpayers. } \\
\square \text { Focusing on the settlement of audit cases which } \\
\text { generate the correct amount of taxes. }\end{array}$ \\
\hline
\end{tabular}

Note: * Key Performance Indicator.

Source: Extracted from IRBM's Annual Report (IRBM, 2016, 2017, 2018).

submission of tax returns by taxpayers (Bozanic et al., 2017). Indicators such as type of firm (multinational or domestic), managerial structure (foreign director or domestic director), type of industry, tax consultants, profitability level as well as audit years were widely used by previous researchers in representing tax audit indicators (Bozanic et al., 2017; Nessa et al., 2016).

Selection of year of assessment (YA) is also postulated to be strongly connected to tax audits. IRBM (2018) revealed that the selection of the year of assessment (YA) for audit is decided through an internal review of a computerised system which is based on risk analysis. Although the data allow for detection of the selection of the year of assessment, the perspective of the tax authority is not clearly grounded, where the criteria used by the tax authority when selecting the year of assessment for tax monitoring is also not listed. However, it is assumed that the year of assessment chosen is based on outcomes from the internally conducted risk analysis, as highlighted in the IRBM's annual report in Table 1.

The next indicator of firm characteristics is the year the actual audit takes place (AYA). AYA does not necessarily occur in the same assessment year selected by the tax authority. For instance, if the internal system chose 2015 as the year of assessment, the real tax audit may be conducted in the subsequent year where the emphasis of audit remain equal. The year where an actual audit is carried out by the assessment officer is usually when communication with a taxpayer is initiated. IRBM will communicate with 
the chosen taxpayer on the audit by issuing a letter of notice. This particular interaction is stored in the internal system and is used to indicate the likelihood of being monitored by the tax authority. Therefore, when the computerised system systematically selects audit cases and contact with taxpayers is initiated by the assessment officers, it is highly likely that a tax audit will take place.

Next, information on the scale of operation of a domestic firm or a multinational firm is related to the indicator used by tax authorities when performing tax authority monitoring (TAM - tax authority monitoring). A research by Kubick et al. (2017) postulated that the IRS is more likely to choose domestic taxpayers, given the close distance to a tax office, incurring a much lower cost for audit. In contrast, findings show that the IRS is disinterested in local firms and conducted an audit examination based on their industry know-how instead. From their survey analysis involving tax directors of multinational firms, Hoopes et al. (2012) revealed that a stricter audit did not prevent firms from applying aggressive tax schemes. In another related research, Beuselinck et al. (2014) claimed that multinational firms took advantage of a weaker tax audit to shift their income. The rationale behind this action is the reliance on variation in the scale of operations. This rationale was supported by Salihu, Annuar and Sheikh Obid (2015), who documented how multinational firms operating in Malaysia were exploiting their international scale of operations to evade taxes. Although multinational firms are more exposed to international tax planning ${ }^{2}$ as compared to domestic firms, Dyreng, Hanlon, Maydew and Thornock (2017) found that both types of firms recorded a similar decreasing trend in ETR.

The managerial structure, whether the firm has a foreign director or domestic director, is linked to the indicator employed by tax authorities in executing tax audit. Previous research proved that a foreign director holds a foreign interest towards the host country (Salihu et al., 2015), besides being interested in cross-border investment (Masulis, Wang, \& Xie, 2012) and monitoring firm performance (Estélyi \& Nisar, 2016). Due to the differentiation between ownership and control, a firm with either a foreign or domestic director can use the complex procedure in corporate taxation to divert the firm's income elsewhere. Salihu et al. (2015) found a significant positive association between a foreign director ${ }^{3}$ and tax avoidance. However, stricter tax audit monitoring can prevent (El Ghoul, Guedhami, \& Pittman, 2011) and render it difficult for directors or managers (insiders) to gain personal benefits (Hanlon et al., 2014). In the light of a stricter audit, Brushwood et al. (2018) found that managers are more cautious when reporting taxes.

In previous literature, industry type has been commonly used as a possible preference by tax authorities when conducting an audit (Ayers et al., 2017; Brushwood et al., 2018; El Ghoul et al., 2011, Kubick et al., 2016). The annual report released by IRBM reported that the course of audit is segmented according to the Industry Based Audit, as shown in Table 1. Since this study concentrates on incentivised firms that are heavily involved in plant and machinery, the identification of industry indicators (ISEC) is deemed informative to the tax authority.

Transfer pricing, international tax system and different accounting systems.

Salihu et al. (2015) used foreign director and foreign shareholding as proxies for foreign interest. 
Hired tax consultants provide accounting and taxation affairs services. According to Frecknall-Hughes and Moizer (2015), services provided by tax consultants are divided into compliance work and tax planning or avoidance advice. Tax compliance serves to ensure that every economic transaction complies with tax law while the role of tax consultants is to serve their clients' best interest. Hence, there are occasions of deliberate manipulation in reducing the amount of tax payable. On the other hand, a tax consultant is considered an additional force in improving corporate governance at the firm level. Hoopes et al.'s (2012) study found that a firm's corporate governance improved when they hire an auditor from the Big Four audit firms, showing negative interactions with tax audit probability. Despite contradicting evidence on the impact of tax consultants (TC), they are predicted to be part of the firm characteristics used by tax authorities when performing tax audits.

Finally, the profitability (ROA - return on assets) and profit versus loss firm status (FS) are conceivably key elements which attract the tax authority to conduct tax audits. The main difference between ROA and FS is that ROA captures the economic magnitude in terms of percentage while FS indicates whether a firm is making profit or loss within the observation year. The government, through tax authorities, has a share of profit in tax payable. Thus, the government is undeniably interested in ensuring that the actual profit earned is reported (Hanlon et al., 2014). The government's or tax authority's interest in firm's profit is reasonable as profitability measured by the ROA has a positive association with tax avoidance (Frank, Lynch, \& Rego, 2009). The positive relationship between profitability and the probability of being selected for a tax audit is further confirmed by Kubick et al. (2016). Instead of excluding loss firms, an additional variable that could explain precisely the loss year status firms and profit year status firms were added.

This study involves all the mentioned variables in explaining indicators that can directly contribute to the selection of tax audits. It is important to note that firm characteristics of the dataset adhere to the year of assessment. Overall, the indicators in firm characteristics are predicted to have a strong association with the likelihood of being selected by the tax authority for a tax audit. Thus, the following hypothesis is proposed:

$\mathrm{H}_{1}$ : Firm characteristics share a significant relationship with the indicators of tax authority monitoring (TAM)

\subsubsection{Tax Avoidance and Tax Authority Monitoring}

Numerous research works (Desai, 2003; Dyreng, Hanlon, \& Maydew, 2008; Frank et al., 2009; Higgins, Omer, \& Phillips, 2015; Lisowsky, 2010; Wilson, 2009) which are focused on advanced taxation system have demonstrated that audit is often induced by tax avoidance indicators such as ETR (Hoopes et al., 2012) as well as book-tax differences (Bozanic et al., 2017). Hoopes et al. (2012) suggested that stricter tax audit enforcement would lead to a decrease in tax avoidance, and subsequently, increase revenue because stricter measures incur less cost and resources in the audit process. According to Bozanic et al. (2017), tax authorities such as the IRS are inherently interested in ETR because this indicator provides specific information on international tax strategies. A higher book-tax difference also indicates higher tax avoidance. The tax authority's focus 
on detecting corporate tax avoidance implies that the indicators used by tax authorities for tax monitoring should ideally be related to tax avoidance indicators, thus giving rise to the second hypothesis:

\section{$\mathrm{H}_{2}$ : Tax avoidance indicators are associated with tax authority monitoring (TAM)}

\subsubsection{Reinvestment Allowance Utilization and Tax Authority Monitoring}

The RA is a special tax relief introduced in 1979 where it was specially designed for manufacturing firms to stimulate investments in automation, modernisation, expansion and diversification of businesses. According to Abd Hamid et al. (2018), the $60 \%$ tax deduction on qualifying capital expenditure provides an opportunity for firms to expand and transform their businesses into a fully automated and modernised operation. Tax monitoring was also observed to increase the effective implementation of RA as a low rate of utilisation in RA among the claiming firms were reported.

In this study, the RA utilisation (RAUTI) is included for two reasons: firstly, all the sample firms involved in this research claimed the RA utilisation, hence, it will be interesting to examine whether the RA utilisation rate is capable of attracting tax audits. The low utilisation rate of RA incentive prompted Abd Hamid et al. (2018) to identify the determinants of incentive utilisation in their research. They found that not all firms that claimed RA was able to fully utilise the incentive as per plan. Secondly, most firms seek to exploit opportunities presented by tax incentives to lower their tax burden where this tax avoidance method is often a strategy in their tax planning. There are various tax incentive implementation issues which need to be considered by governments and policymakers, such as the flouting of qualifying conditions and continuous monitoring compliance as well as the possible misuse of tax incentives. The continuous monitoring of incentives is fundamentally essential to prevent the misappropriation of tax incentives. For instance, Zolt (2014) raised several strategies in the case of tax incentives abuse including fictitious investments, overvaluation of assets, manipulation of the non-qualifying activities, and the transfer of pricing schemes to related entities. Taking these issues into consideration, a tax audit conducted by IRBM is most likely to concentrate on how a firm fully utilises the RA incentive. Thus, the third hypothesis is proposed as follows:

$\mathrm{H}_{3}$ : Reinvestment Allowance Utilisation (RAUTI) is associated with tax authority monitoring (TAM)

\section{Sample Selection and Research Design}

The data were collected and merged from two sources: i) the administrative tax return data, ${ }^{4}$ and ii) the historical tax audit record of taxpayers that were internally generated by the case management system (CMS). The confidentiality of tax information received from IRBM was protected throughout this research. As such, statistical aggregates were

4 Compiled by the Statistical and Analytic Division of Tax Operations Department of the Inland Revenue Board of Malaysia (IRBM). 
used to ensure anonymity, preventing specific taxpayers from being identified through the information provided by IRBM.

A total of 7,153 companies were reported to have claimed RA from 2007 to 2016, however, this number fluctuates each year. The data collected contains only firms which claim and carry forward unused RA. For example, if a firm reported RA claim in 2015 but did not report any RA in the following year, the complete details would not be available in 2016. Therefore, the data of certain companies may be unavailable. For the purpose of this study, only firms which claimed RA or carried forward any unused RA were chosen as samples. This key selection criterion allows for a balanced panel data of the incentivised companies and firms with complete information, maintaining the consistency of the outcomes. It is important to note that a firm excluded from the sample does not mean there is no chance for tax audit to occur, instead, the exclusion is simply to strengthen the validity of data analysis.

Table 2 describes the criteria for sample selection which involve companies with both excessive losses and profits where the year of assessment for these firms will be according to their respective financial year. The guidelines from Noor, Mastuki and Bardai's (2008) study was used to filter the sample, eliminating companies with extreme ROA values and retaining firms with ROA of not more than $100 \%$ (or $-100 \%$ ). Data filtering is essential as the thorough selection of these firms can influence the understanding of the relationship between firms with loss or profit and TAM. After performing multiple data filtration, a total of 401 samples and 4,010 completed observations (10 observation years) were identified. These samples were then matched with the tax audit record of the CMS according to the observation years.

\subsection{Regression Specifications}

The objective of this research is to examine the indicators in firm characteristics, tax avoidance and RA utilisation which may influence tax monitoring executed by the tax

Table 2. Sample selection criteria

\begin{tabular}{|c|c|c|}
\hline Data & Criteria & No. of firm \\
\hline \multirow[t]{6}{*}{ Tax return } & Total sample frame of firms utilising RA. & 7,153 \\
\hline & Exclusion: & \\
\hline & $\begin{array}{l}\text { Firms that did not utilise RA in all observation years } \\
\text { (2006-2017). }\end{array}$ & $(5,955)$ \\
\hline & $\begin{array}{l}\text { Full sample inclusive of firms reporting positive and } \\
\text { negative nett income. }\end{array}$ & 1,198 \\
\hline & Restriction: & \\
\hline & $\begin{array}{l}\text { Firms reported extreme values of ROA more than } \\
100 \% \text { and }-100 \% \text {. Firms with incomplete variables data. }\end{array}$ & $(797)$ \\
\hline Audit record & $\begin{array}{l}\text { The final sample of profit and loss firms matched with } \\
\text { the historical audit record. }\end{array}$ & 401 \\
\hline Firm-year observation & 401 firms for ten observation years. & 4,010 \\
\hline
\end{tabular}


authority. Accordingly, a regression model was developed to examine the relationship between firms experiencing tax audits and firm characteristics, measures of tax avoidance and RA utilisation. The proposed regression model is as follows:

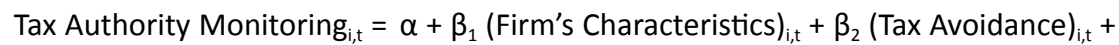

$$
\beta_{3}(\text { RA Utilisation })_{i, t}+\varepsilon_{i, t}
$$

The tax authority monitoring model produces a dichotomous outcome of both a tax-monitored firm and an unmonitored tax firm. The binary logistic regression ${ }^{5}$ was employed to predict the indicators for tax authority monitoring (TAM). In this research, firms that experienced tax authority monitoring during the observation period of 2016 to 2017 were indicated as "1" while firms that did not undergo tax authority monitoring were assigned a " 0 ". The two tax audit approaches, be it field or desk audit, were treated as a single unit where tax audit can be either one of the approaches. Furthermore, the firm's characteristics, tax avoidance and RA utilisation were set as predictor variables when examining the indicators for tax authority monitoring. Firm characteristics consist of rich data such as year of assessment (YA), actual years of audit (AYA), return on assets (ROA), firm status (FS), taxpayer profiles (TPP), industrial sectors (ISEC), firm's directorship (FD) and tax consultant (TC). Tax avoidance strategy comprises of the two most common approaches namely, the effective tax rate (ETR) and book-tax difference (BTD). Finally, the RA utilisation as a predictor variable serves to examine the indicators used by tax authorities before executing a tax audit. In the next section, the measurement of all other variables is clearly explained.

\subsection{Variable Definitions}

Table 3 provides descriptions on the different variables which were selected for the empirical analysis of this study.

Table 3. Measurement of variables

\begin{tabular}{ll}
\hline Variable & \multicolumn{1}{c}{ Measurement of variable } \\
\hline YA & $\begin{array}{l}\text { An internal computerised system of IRBM which is identified as year of assessment. } \\
\text { The year of assessment assigned by the system is indicated as " } 1 \text { " at year } t \text { and " } 0 \text { " for } \\
\text { years not selected. }\end{array}$ \\
AYA & $\begin{array}{l}\text { The actual year of audit conducted by the tax officer. The actual year is indicated as " } 1 \text { " } \\
\text { at year } t \text { and " } 0 \text { " when the actual audit has not occurred. }\end{array}$ \\
ETR & $\begin{array}{l}\text { Known as the effective tax rate measured by tax payable divided by nett accounting } \\
\text { income. }\end{array}$ \\
RAUTI & $\begin{array}{l}\text { Reinvestment allowance (RA) utilisation (in percentage) measured by RA claimed } \\
\text { during the year divided by the actual maximum amount of RA at year } t .\end{array}$ \\
ROA & $\begin{array}{l}\text { Return on assets proxy in terms of a firm's level of profitability. ROA is measured by } \\
\text { nett accounting income divided by total assets. }\end{array}$
\end{tabular}

5 Logistic regression is used to test models in predicting categorical outcomes (Pallant, 2016). 
Table 3. Continued

\begin{tabular}{|c|c|}
\hline Variable & Measurement of variable \\
\hline BTD & $\begin{array}{l}\text { Book-tax difference computed by comparing pre-tax book income against the } \\
\text { estimated taxable income. A large BTD is usually a sign of tax avoidance and warrants } \\
\text { further investigation. }\end{array}$ \\
\hline FD & $\begin{array}{l}\text { Firm directorship is a categorical variable. The presence of a foreign director in a firm is } \\
\text { referred to as FDIR, with DDIR representing a domestic director. }\end{array}$ \\
\hline \multirow[t]{4}{*}{ TPP } & Taxpayer profiles (TPP) refers to: \\
\hline & $\begin{array}{l}\text { Multinational taxpayers are abbreviated to "TPP3" where: (i) total income, income } \\
\text { from other business sources and profits generated from related foreign firms exceeds } \\
\text { RM } 25 \text { million, (ii) sales, purchases, total expenditure incurred, and total income } \\
\text { generated from related foreign firms exceeds RM15 million, and (iii) loans made to or } \\
\text { from a related foreign firm. }\end{array}$ \\
\hline & Big taxpayers are denoted as "TPP2", where sales exceed RM30 million. \\
\hline & Regular taxpayers are denoted as "TPP1" where sales do not exceed RM30 million. \\
\hline TC & $\begin{array}{l}\text { Tax consultant is a dummy variable for firms that engaged the services of the Big Four } \\
\text { audit firms indicated as " } 1 \text { " and " } 0 \text { " for non-Big Four. }\end{array}$ \\
\hline ISEC & $\begin{array}{l}\text { Sector industry is a dummy variable categorised according to the firm's core business: } \\
1 \text { for electrical and electronics, } 2 \text { for metal and minerals, } 3 \text { for food and beverage, } 4 \text { for } \\
\text { textile and garment, } 5 \text { for wood, paper and printing, } 6 \text { for petroleum, chemical, rubber } \\
\text { and plastics, } 7 \text { for automobile, equipment and other manufacturing, and finally, } 8 \text { for } \\
\text { agriculture. }\end{array}$ \\
\hline FS & $\begin{array}{l}\text { Firm status is a dummy variable for firms reporting positive profits in } t \text { years where } \\
\text { they are indicated as " } 1 \text { " at year } t \text {, while for firms reporting losses at year } t \text {, the } \\
\text { indication is " } 0 \text { ". }\end{array}$ \\
\hline
\end{tabular}

\section{Results}

The binary logistic regression was performed to predict the association of the number of variables on the possible indicators used by tax authorities to execute tax audits. Table 4 shows the observation and categorical variable coding. Each variable was observed and reported to complete 4,010 frequency of occurrence. Among the highest frequency recorded is the TAM variable with $84 \%$ and the FS (profit) variable with $81.8 \%$. Table 5 presents the descriptive statistics for ETR, BTD, ROA and RA utilisation. The statistical output displays the summary of mean, median, standard deviation for 4,010 company-year observations. For each variable recorded, a $95 \%$ confidence interval for mean within the lower and upper boundary was observed.

Table 6 demonstrates the main results of the logistic regression analysis where the $\operatorname{EXP}(\beta)$ column represents the odds ratio for the individual variable, while the $\mathrm{SE}$ column reflects the standard error around the coefficient for the constant. Only firm characteristics indicators such as YA, AYA, ROA, FS, TPP2, FD1 and ISEC 2, 4, 5, 6,7 showed a unique statistically significant contribution to the model of predicting 
Table 4. Categorical variable coding

\begin{tabular}{|c|c|c|c|}
\hline Variable & Description and coding & Frequency & Percent (\%) \\
\hline Experience tax & No -0 & 630 & 15.7 \\
\hline monitoring (TAM) & Yes - 1 & 3,380 & 84.3 \\
\hline Year of assessment & No -0 & 3,173 & 79.1 \\
\hline (YA) & Yes - 1 & 837 & 20.9 \\
\hline Actual year audit & No -0 & 2,952 & 73.6 \\
\hline (AYA) & Yes - 1 & 1,058 & 26.4 \\
\hline Firm status & Loss - 0 & 730 & 18.2 \\
\hline (FS) & Profit - 1 & 3,280 & 81.8 \\
\hline Taxpayer profiles & Regular taxpayer - 1 & 2,140 & 53.4 \\
\hline \multirow[t]{2}{*}{ (TPP) } & Big taxpayer - 2 & 1,390 & 34.7 \\
\hline & Multinational taxpayer - 3 & 480 & 12.0 \\
\hline Industrial Sectors & Electrical and electronics - 1 & 560 & 14.0 \\
\hline \multirow[t]{7}{*}{ (ISEC) } & Metal and minerals - 2 & 660 & 16.5 \\
\hline & Food and beverage - 3 & 350 & 8.7 \\
\hline & Textile and garments - 4 & 80 & 2.0 \\
\hline & Wood, paper and printing - 5 & 940 & 23.4 \\
\hline & Petroleum, chemical, rubber and plastics - 6 & 710 & 17.7 \\
\hline & $\begin{array}{l}\text { Automobile, equipment and other } \\
\text { manufacturing }-7\end{array}$ & 610 & 15.2 \\
\hline & Agricultural (Palm oil and livestock) - 8 & 100 & 2.5 \\
\hline Firm directorship & Domestic director - 0 & 2,790 & 69.6 \\
\hline (FD) & Foreign director - 1 & 1,220 & 30.4 \\
\hline Tax consultant & Non-Big Four auditor - 0 & 2,690 & 67.1 \\
\hline$(\mathrm{TC})$ & Big Four auditor -1 & 1,320 & 32.9 \\
\hline Total & & 4,010 & $100 \%$ \\
\hline
\end{tabular}

Note: Definitions of variables are provided in Table 3.

Table 5. Descriptive statistics for ETR, RAUTI, ROA and BTD

\begin{tabular}{lccccrrr}
\hline Variables & Mean & Median & Variance & $\begin{array}{c}\text { Std. } \\
\text { deviation }\end{array}$ & Min. & Max. & Range \\
\hline ETR & 0.0887 & 0.0528 & 0.0167 & 0.1291 & 0 & 1 & 1 \\
RAUTI & 0.3460 & 0.1165 & 0.1705 & 0.4129 & 0 & 1 & 1 \\
ROA & 0.0543 & 0.0510 & 0.0234 & 0.1528 & -0.9926 & 0.9993 & 1.9919 \\
BTD & 0.0355 & 0.0209 & 0.0030 & 0.0544 & -0.3328 & 0.9829 & 1.3157 \\
\hline
\end{tabular}

Note: Definitions of variables are provided in Table 3. 
Table 6. Variables in the equation

\begin{tabular}{lrrrrr}
\hline Indicator Variables & \multicolumn{1}{c}{$\mathrm{B}$} & \multicolumn{1}{l}{ SE } & Wald & Sig. & EXP( $\beta$ ) \\
\hline FS (Profit) & .419 & .165 & 6.460 & $.011^{*}$ & 1.520 \\
ROA & -1.075 & .449 & 5.722 & $.017^{*}$ & .341 \\
TPP(1) & -.098 & .118 & .681 & .409 & .907 \\
TPP(2) & -.464 & .174 & 7.141 & $.008^{*}$ & .629 \\
FD(FDIR) & -.479 & .120 & 15.920 & $.000^{*}$ & .620 \\
ISEC(1) & -.056 & .159 & .125 & .724 & .946 \\
ISEC(2) & 2.089 & .349 & 35.860 & $.000^{*}$ & 8.078 \\
ISEC(3) & -.521 & .283 & 3.374 & .066 & .594 \\
ISEC(4) & 1.324 & .180 & 54.171 & $.000^{*}$ & 3.757 \\
ISEC(5) & .330 & .163 & 4.087 & $.043^{*}$ & 1.391 \\
ISEC(6) & .496 & .167 & 8.866 & $.003^{*}$ & 1.642 \\
ISEC(7) & .904 & .374 & 5.834 & $.016^{*}$ & 2.469 \\
TC(Big Four) & .492 & .125 & 15.452 & $.000^{*}$ & 1.635 \\
YA (1) & 4.510 & .711 & 40.259 & $.000^{*}$ & 90.907 \\
AYA(1) & 2.406 & .224 & 115.074 & $.000^{*}$ & 11.090 \\
ETR & -.512 & .451 & 1.292 & .256 & .599 \\
BTD & -.647 & 1.047 & .381 & .537 & .524 \\
RAUTI & .014 & .141 & .009 & .002 & 1.014 \\
Constant & .537 & .175 & 9.452 & 1.711 \\
\hline
\end{tabular}

Note: Definitions of variables are provided in Table 3. *Statistical analysis: tested at significance level of $\alpha=$ 0.05 ( $p$-value) with 95\% confidence interval.

indicators applied by tax authorities for tax monitoring. Of the listed firm characteristic variables, ROA, TPP2, and FDIR show a negative sign, indicating that the odds of TAM decreases when a firm has a high level of profitability (ROA), categorised as a big taxpayer (TPP2) and has a foreign director on the board (FDIR). In other words, a firm that has higher level profitability (ROA) was 0.341 times less likely to experience tax authority monitoring than firms reporting a low level of profitability. The coefficients also indicated that the odds of "Big Taxpayer" (TPP2) to TAM were 0.629 times lower than the regular and multinational taxpayers while the possibility of firms with foreign directors was 0.620 times less likely to experience tax audit enforcement. On the other hand, the most significant indicator of TAM is the year of assessment (YA) detected by the internal computerised system of IRBM where it recorded an odd ratio of 91.01, implying that the internal computerised system identified that a firm is over 91 times more likely to experience TAM than a firm that was not selected by the system. The odds ratio of 11.0 for AYA, indicate that as more communication was initiated by the tax officer, the taxpayer was 11 times more likely to face a TAM. In terms of firm status, the odds ratio shows that a profitable firm has a higher chance of being selected (1.52 times) as compared to a loss-making firm. Furthermore, all industry sectors (ISEC) are 
reported to have significant coefficient to TAM, except for electrical and electronics (ISEC1) and food and beverage (ISEC3) industries. Moreover, the odds of the Big Four audit firms hired by the firm were 1.635 higher than firms hiring non-Big Four audit firms in TAM selection. Contrary to the prediction of the study, the indicator variables for tax avoidance, such as ETR, BTD and RA utilisation reported insignificant coefficients in this model.

The model summary results provide values for two pseudo $\mathrm{R}^{2}$ values. The model, as a whole, reported values of $17.3 \%$ (Cox and Snell R squared) and $29.8 \%$ (Nagelkerke $R$ squared), suggesting that between $17.3 \%$ and $29.8 \%$ of the variability of TAM is explained by the variables used in this study. The model sensitivity output is the percentage of the firm experiencing TAM or not experiencing TAM that has been correctly identified by the model. Based on the data in Table 7, 99\% of the firms which experienced TAM were accurately classified, while the correctly classified firms are reported to be $83.7 \%$. This result indicates the strong reliability of the model employed.

Table 7. Model sensitivity

\begin{tabular}{|c|c|c|c|c|}
\hline & & \multicolumn{3}{|c|}{ Predicted } \\
\hline \multicolumn{2}{|c|}{ Observed } & \multicolumn{2}{|c|}{ TAM } & \multirow{2}{*}{ Percentage correct } \\
\hline & & No & Yes & \\
\hline \multirow{2}{*}{ TAM } & No & 11 & 619 & 1.7 \\
\hline & Yes & 33 & 3347 & 99.0 \\
\hline \multicolumn{4}{|c|}{ Overall percentage } & 83.7 \\
\hline
\end{tabular}

\section{Discussion}

This study mainly focused on rational predictions for tax audit occurrence in firms by relying on firm characteristics and tax avoidance indicators for an observable period of 10 years. Considering the complexity and possible abuse of RA, its utilisation percentage was included as one of the possible indicators. Overall, the binary logistic equation showed that firm characteristics indicators were found to be associated with tax audit occurrence while tax avoidance and RA utilisation indicators were not as significantly apparent.

Although the sensitivity model correctly predicted a high percentage $(83.7 \%)$ of firms experiencing tax audit while providing 4,010 complete firm observations, these results need to be interpreted carefully since the sample consists of firms claiming RA. Thus, the findings from this research cannot represent the entire corporate taxation population despite the inclusion of various types of corporate taxpayers such as multinational firms, big taxpayers and regular taxpayers in a bid to widen the research interest for this study. The logistic equation reported that all indicators in firm characteristics tested on TAM are significant and is consistent with hypothesis $\mathrm{H} 1$. The strongest predictor of a firm experiencing tax audit is found to be YA. Other indicators such as AYA, FS, ROA, TPP2, FDIR, TC and ISEC 2, 4, 5, 6, 7 showed significant 
association toward tax audit execution, supporting the remaining hypotheses tested on firm characteristics.

As noted earlier, ROA measures the level of profitability, while FS is a categorical variable measuring the profit or loss status of the firm. Interestingly, the level of a firm's profitability showed a negative association with TAM. On the other hand, FS is reported to share a positive association with TAM. This outcome indicates that a firm with a high level of profitability was less likely to be selected for tax authority monitoring. Nevertheless, the profitable firm still has a higher chance of being selected for an audit as compared to firms making losses. In line with Bozanic et al. (2017), this outcome indicates that the selection of tax audit is indeed based on a decreasing trend in profit where firms are approaching loss status. On the other hand, Mills (1998) and Hanlon and Slemrod (2009) also claimed that firms experiencing losses have a lower probability of facing an audit. The results of this study confirm this when firms reporting negative profit throughout the year of observation were discovered to receive less attention from the tax authority versus firms that show a positive profit. This inattention is perhaps due to a lower chance of engaging tax avoidance strategies among loss-making firms (Ayers et al., 2017).

Moreover, Hoopes et al. (2012) claimed that firms were better governed and possessed a higher value when they appointed tax consultants from the Big Four firms. Nevertheless, findings proved that hiring tax consultants from the Big Four firms do not deter firms from being selected by tax authorities. Next, the industry sector indicator showed a significant predictor of TAM except for electrical and electronics as well as food and beverage industries. This outcome can be attributed to the industry based audit approach employed by IBRM to conduct tax audits. Thus, the significant association of ISEC on TAM is not surprising and strongly supports the hypothesis. This association indicates that the information on industry types may be beneficial to tax authorities when conducting tax audits.

The measure for tax authority monitoring is based on whether firms experienced tax audit during the 10-year observation period. Instead of using probability rates or public information disclosure conducted in researches by Bozanic et al. (2017) and Hoopes et al. (2012), actual tax audit information was employed to analyse firms that experience tax audit. The predictor for tax avoidance measured by ETR and BTD as well as indicators of RA utilisation were reported to have no association with TAM. These results were inconsistent with the notion that tax authority prefers tax avoidance measures and percentage of incentive utilisation when deciding to conduct a tax audit. It can be concluded that the execution of a tax audit focuses on regular tax compliance issues rather than a detailed examination of the intensity of firms claiming tax benefits. These results shed some light on possible areas of consideration for tax authorities before initiating tax audits.

\section{Conclusion and Implications}

In sum, firm characteristics are strongly associated with the indicators used by the tax authority, since they make a unique, statistically significant contribution to the logistic regression model. The assessment year based on internal review results, the profit 
status of firms, type of industry, firm categories as big taxpayer and hiring of tax consultants are also positively associated with the indicators of tax authority monitoring. This study also extends to include utilised RA in the data analysis. However, in terms of tax-related attributes, the RA utilisation rate, effective tax rate and the book-tax difference are unrelated to the indicators employed by the tax authority when conducting tax monitoring. Moreover, the firm's level of profitability, big taxpayer profile and firm directorship are found to be significant but negatively related to tax monitoring. This finding suggests that indicators for tax monitoring increases with firm characteristics but are not related to tax avoidance and tax incentive utilisation measures.

The investigation conducted in this study allows for a better understanding of the indicators used by tax authorities to carry out tax audits. The motive for selecting and conducting audits is observed to mainly deter incompliance as well as to detect risks associated with firm characteristics. In terms of firms experiencing losses, the insignificant result suggests that tax auditors has ignored this type of firms. Therefore, the RA claimed by loss-making firms may not be fully understood since the tax position of these firms remains unknown. Corporate taxpayers can also draw from this research by being better prepared as the tax audit occurrence is reported to be high (84.3\%), indicating a high possibility for these corporate firms to be selected for a tax audit. In terms of strengthening the tax audit governance, IRBM may want to consider more ubiquitous indicators involving profit-shifting activities among corporate taxpayers. These profit-shifting activities can include transfer pricing, financing structures or the relocation of assets across the country to lower corporate tax burden.

More importantly, this research revealed new evidence on the areas relevant to tax authorities and tax audit enforcement. This study may be considered preliminary to propose policy prescriptions for the tax authority to concentrate on tax avoidance indicators and RA incentive utilisation but it provides useful insights to alternative indicators employed by tax authorities in enforcing tax audit governance.

\section{References}

Abd Hamid, N., A. Hamzah, F.H., Noor, R.M., \& Azali, N.M. (2018). Determinants of reinvestment allowance (RA) tax incentive utilization in Embracing Industry 4.0. Polish Journal of Management Studies, 18(2), 94-104. https://doi.org/10.17512/pjms.2018.18.2.08

Ayers, B.C., Seidman, J.K., \& Towery, E. (2017). Taxpayer behavior under audit certainty. SSRN Electronic Journal: 2609134. https://doi.org/10.2139/ssrn.2609134

Bank Negara Malaysia. (2017). Rethinking investment incentives. BNM Quarterly Bulletin, 3rd Quarter. Kuala Lumpur: Author. Retrieved from http://www.bnm.gov.my/files/publication/ qb/2017/Q3/p3_ba1.pdf

Beuselinck, C., Deloof, M., \& Vanstraelen, A. (2014). Cross-jurisdictional income shifting and tax enforcement: Evidence from public versus private multinationals. Review of Accounting Studies, 20(2), 710-746. https://doi.org/10.1007/s11142-014-9310-y

Bozanic, Z., Thornock, J.R., Hoopes, J.L., \& Williams, B.M. (2017). IRS Attention. Journal of Accounting Research, 55(1), 79-114. https://doi.org/10.1111/1475-679X.12154

Brushwood, J.D., Johnston, D.M., \& Lusch, S J. (2018). The effect of tax audit outcomes on the reporting and valuation of unrecognized tax benefits. Advances in Accounting, 42(April), 1-11. https://doi.org/10.1016/j.adiac.2018.06.001 
Desai, M.A. (2003). The divergence between book income and tax income. Tax Policy and the Economy, 17 (January), 169-206. https://doi.org/10.1086/tpe.17.20140508

Desai, M., Dyck, A., \& Zingles, L. (2007). Theft and taxes. Journal of Financial Economics, 84(3), 591-623. https://doi.org/10.1016/j.jfineco.2006.05.005

Dyreng, S.D., Hanlon, M., \& Maydew, E.L. (2008). Long-run corporate tax avoidance. The Accounting Review, 83(1), 61-82. https://doi.org/10.2308/accr.2008.83.1.61

Dyreng, S.D., Hanlon, M., Maydew, E.L., \& Thornock, J.R. (2017). Changes in corporate effective tax rates over the past 25 years. Journal of Financial Economics, 124(3), 441-463. https://doi. org/10.1016/j.jfineco.2017.04.001

El Ghoul, S., Guedhami, O., \& Pittman, J. (2011). The role of IRS monitoring in equity pricing in public firms. Contemporary Accounting Research, 28(2), 643-674. https://doi.org/10.1111/ j.1911-3846.2011.01065.x

Estélyi, K S., \& Nisar, T.M. (2016). Diverse boards: Why do firms get foreign nationals on their boards? Journal of Corporate Finance, 39(August), 174-192. https://doi.org/10.1016/j. jcorpfin.2016.02.006

Frank, M.M., Lynch, L.J., \& Rego, S.O. (2009). Tax reporting aggressiveness and its relation to aggressive financial reporting. The Accounting Review, 84(2), 467-496. https://doi. org/10.2308/accr.2009.84.2.467

Frecknall-Hughes, J., Moizer, P. (2015). Assessing the quality of services provided by UK tax practitioners. EJournal of Tax Research, 13(1), 51-75.

Guedhami, O., \& Pittman, J. (2008). The importance of IRS monitoring to debt pricing in private firms. Journal of Financial Economics, 90(1), 38-58. https://doi.org/10.1016/j.jfineco. 2007.12.002

Hanlon, M., Hoopes, J.L., \& Shroff, N. (2014). The effect of tax authority monitoring and enforcement on financial reporting quality. Journal of the American Taxation Association, 36(2), 137170. https://doi.org/10.2308/atax-50820

Hanlon, M., \& Slemrod, J.B. (2009). What does tax aggressiveness signal? Evidence from stock price reactions to news about tax shelter involvement. Journal of Public Economics, 93(1-2), 126-141. https://doi.org/10.2139/ssrn.975252

Henry, E., \& Sansing, R. (2018). Corporate tax avoidance: Data truncation and loss firms. Review of Accounting Studies, 23(3), 1042-1070. https://doi.org/10.1007/s11142-018-9448-0

Higgins, D., Omer, T.C., \& Phillips, J.D. (2015). The Influence of a firm's business strategy on its tax aggressiveness. Contemporary Accounting Research, 32(2), 674-702. https://doi. org/10.1111/1911-3846.12087

Hoopes, J.L., Mescall, D., \& Pittman, J.A. (2012). Do IRS audits deter corporate tax avoidance? The Accounting Review, 87(5), 1603-1639. https://doi.org/10.2308/accr-50187

Inland Revenue Board of Malaysia (IRBM). (2015). Tax Audit Framework. Kuala Lumpur: Author. Retrieved from http://www.hasil.gov.my/pdf/pdfam/tax_audit_framework_2015.pdf

Inland Revenue Board of Malaysia (IRBM). (2016). Annual Report 2015. Kuala Lumpur: Author.

Inland Revenue Board of Malaysia (IRBM). (2017). Annual Report 2016. Kuala Lumpur: Author.

Inland Revenue Board of Malaysia (IRBM). (2018). Annual Report 2017. Kuala Lumpur: Author.

Kubick, T.R., Lockhart, G.B., Mills, L.F., \& Robinson, J.R. (2017). IRS and corporate taxpayer effects of geographic proximity. Journal of Accounting and Economics, 63(2-3), 428-453. https://doi. org/10.1016/j.jacceco.2016.09.005

Lisowsky, P. (2010). Seeking shelter : Empirically modeling tax shelters using financial statement information. The Accounting Review, 85(5), 1693-1720. https://doi.org/10.2308/accr. 2010.85.5.1693

Masulis, R.W., Wang, C., \& Xie, F. (2012). Globalizing the boardroom-the effects of foreign directors on corporate governance and firm performance. Journal of Accounting and Economics, 53(3), 527-554. https://doi.org/10.1016/j.jacceco.2011.12.003 
MICPA, MIA, \& CTIM. (2019). 2019 Budget Commentary and Tax Information. Kuala Lumpur: Authors.

Mills, L.F. (1998). Book-tax differences and internal revenue service adjustments. Journal of Accounting Research, 36(2), 343-356. https://doi.org/10.2307/2491481

Murphy, K. (2008). Enforcing tax compliance: To punish or persuade? Economic Analysis and Policy, 38(1), 113-135. https://doi.org/10.1016/S0313-5926(08)50009-9

Nessa, M., Schwab, C., Stomberg, B., \& Towery, E. (2016). How do IRS resources affect the tax enforcement process? (Working Paper). Retrieved from https://www.ntanet.org/wp-content/ uploads/proceedings/2016/158-nessa-schwab-stomberg-towery-irs-resources-paper.pdf

Noor, R.M., Mastuki, N.A., \& Bardai, B. (2008). Corporate effective tax rates: A study on Malaysian public listed companies. Malaysia Accounting Review, 7(1), 1-20.

Pallant, J. (2016). SPSS Survival Manual (6th Ed). London, UK: McGraw-Hill Education.

Salihu, I.A., Annuar, H.A., \& Sheikh Obid, S.N. (2015). Foreign investors' interests and corporate tax avoidance: Evidence from an emerging economy. Journal of Contemporary Accounting \& Economics, 11(2), 138-147. https://doi.org/10.1016/j.jcae.2015.03.001

Tennant, S.N., \& Tracey, M.R. (2019). Corporate profitability and effective tax rate: The enforcement effect of large taxpayer units. Accounting and Business Research, 49(3), 342-361. https://doi.org/10.1080/00014788.2018.1512398

Wilson, R.J. (2009). An examination of corporate tax shelter participants. The Accounting Review, 84(3), 969-999. https://doi.org/10.2308/accr.2009.84.3.969

Zolt, E.M. (2014). Tax incentives and tax base protection issues (Papers on Selected Topics in Protecting the Tax Base of Developing Countries. Draft Paper No. 3). Retrieved from https:// www.un.org/esa/ffd/wp-content/uploads/2014/10/20140604_Paper3_Zolt.pdf 